\title{
Impact of Socio-Economic Factors and Water Quality on Human Health in Rural Areas of Bufundi Sub County in Uganda: Implications for Policy and Practice
}

\author{
David Safari ${ }^{1}$, Timothy Downs ${ }^{2}$ and Mulongo George ${ }^{3}$ \\ ${ }^{1}$ Department of Environmental Science, Macquarie University, Sydney, NSW, Australia \\ ${ }^{2}$ International Development, Community and Environment (IDCE), Clark University, 950 Main St, Worcester, MA 01610, USA \\ ${ }^{3}$ Department of Chemistry, Gulu University, Gulu, Uganda
}

*Corresponding author: David Safari, Department of Environmental Science, Macquarie University, Sydney, NSW, Australia, Tel: +61468541930; E-mail: david.safari@hdr.mq.edu.au

Received date: October 27, 2016; Accepted date: November 04, 2016; Published date: November 07, 2016

Copyright: ( 2017 Safari D, et al. This is an open-access article distributed under the terms of the Creative Commons Attribution License, which permits unrestricted use, distribution, and reproduction in any medium, provided the original author and source are credited.

\begin{abstract}
The study demonstrates how socio-economic factors and water quality issues have influenced human health (diarrheal and skin infections) concerns in the local communities of Bufundi sub county, south western part of Uganda. The socio-economic factors of concern included level of education, number of people in a household, incomes, water storage, water treatment and water sources. Water appearance, nitrogen compounds, and coli forms in river, spring and gravity water sources were determined. A questionnaire and laboratory analyses were applied to generate data. Results show that the chi-square values for the discriminant function between diseased and nondiseased were 30.95 and 25.48 ( $p=0.001)$ for diarrhea and skin infection respectively. Most the respondents $(68.9 \%)$ obtained their water from river and spring water sources, and $77.4 \%$ never covered water drinking containers. Results show total coliforms to be 5 times higher $(650 \mathrm{CFU} / 100 \mathrm{ml})$ in river water than international standards.
\end{abstract}

Keywords: Socio-economic factors; Water quality; Human health; Disease

\section{Introduction}

Wright and Boisson reported that many people (884 million) worldwide lack access to improved water resources; hundreds of millions rely on improved sources that are not consistently safe for drinking, and this is responsible for the death of more than 1.8 million people per annum due to diarrhea related diseases in developing countries [1-3]. Moreover, more than 3-quarters of Africa's drinking water come from ground water which has declined increasingly due to contaminations with microbial communities and potentially toxic substances $[4,5]$ demonstrated that open water sources such as ponds, streams, rivers, lakes, swamps, water holes, unprotected springs and shallow wells are the typical water sources in Uganda. Studies by Ref. [6-16] have shown that poor water quality is responsible for most of the human health concerns due to waterborne diseases such as diarrhea, cholera, skin infections and several other diseases. Indicated that more than 100 species of pathogenic bacteria, viruses and protozoa can be found in contaminated water [17-21] through epidemiological evidence show that the most important risk factors to these disease infections are behaviors that encourage human contact with fecal matter including improper disposal of feces, poor sanitation practices such as open pit latrines, and lack of hand washing after defecation $[22,23]$ and the above studies associate poor water quality and human health concerns to factors including among others the socio-economic factors such as agriculture, human settlement, general hygiene and sanitation practices, low income of households, low levels of education, and poor water storage, treatment and fetching practices.
Bufundi Sub-County is located north East of Kabale District, South Western region in Uganda (Figure 1). It is situated between latitude $01^{\circ} 19^{\prime}$ South and longitude $29^{\circ} 52^{\prime}$ East. It has a population of about 33,300 with about 50 functional protected spring water sources accessed by $60 \%$ of the population. The rest of the population (40\%) obtains water from open water sources such as rivers, wells, and ponds.

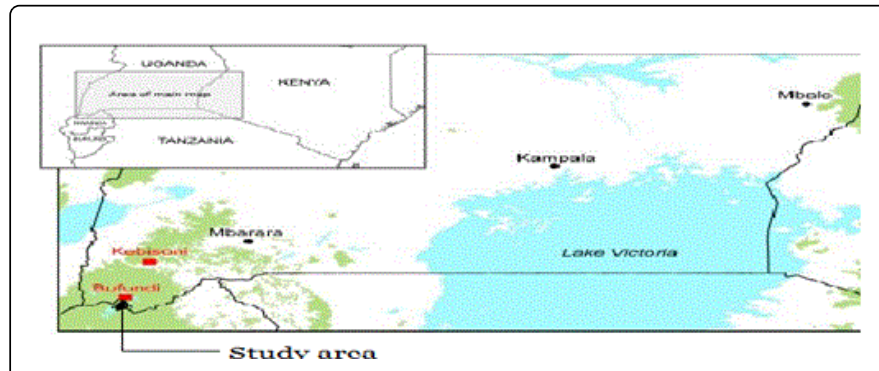

Figure 1: Map showing study area in Uganda.

Bufundi Sub County's topography is described by steep slopes, where people construct terraces for farming. Due to these steep slopes, the area is vulnerable to natural calamities such as landslides, soil erosion and rapid loss of habitat and diversity. Water sources are communal and act for both human and animal water sources for drinking and use (Figures 2 and 3). 
Citation: Safari D, Downs T, George M (2016) Impact of Socio-Economic Factors and Water Quality on Human Health in Rural Areas of Bufundi Sub County in Uganda: Implications for Policy and Practice. Adv Recycling Waste Manag 2: 118. doi:10.4172/2475-7675.1000118

Page 2 of 6

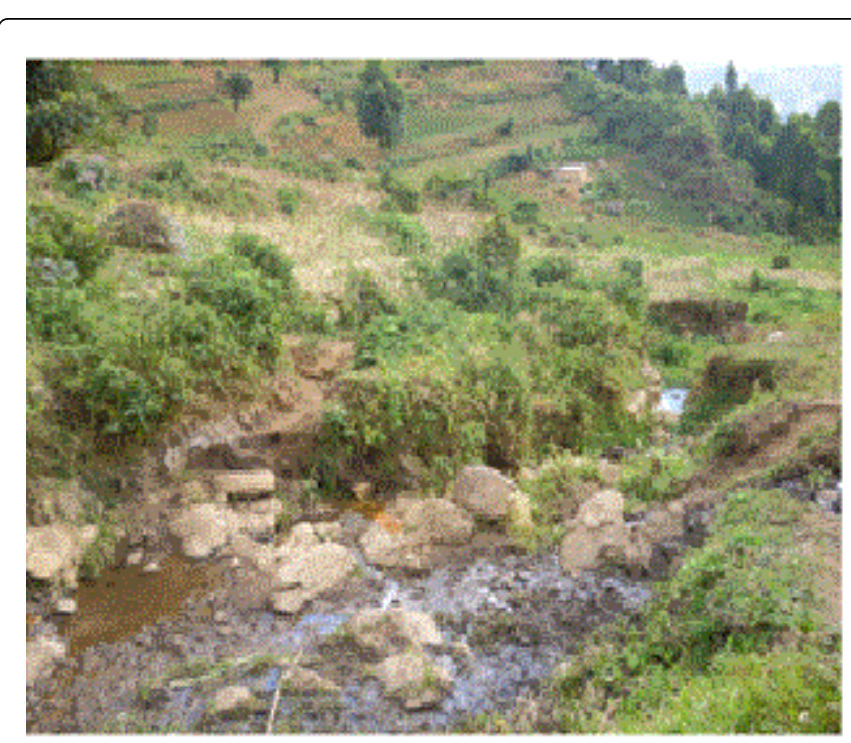

Figure 2: Water collection and cattle drinking point in Rutegyengyere village.

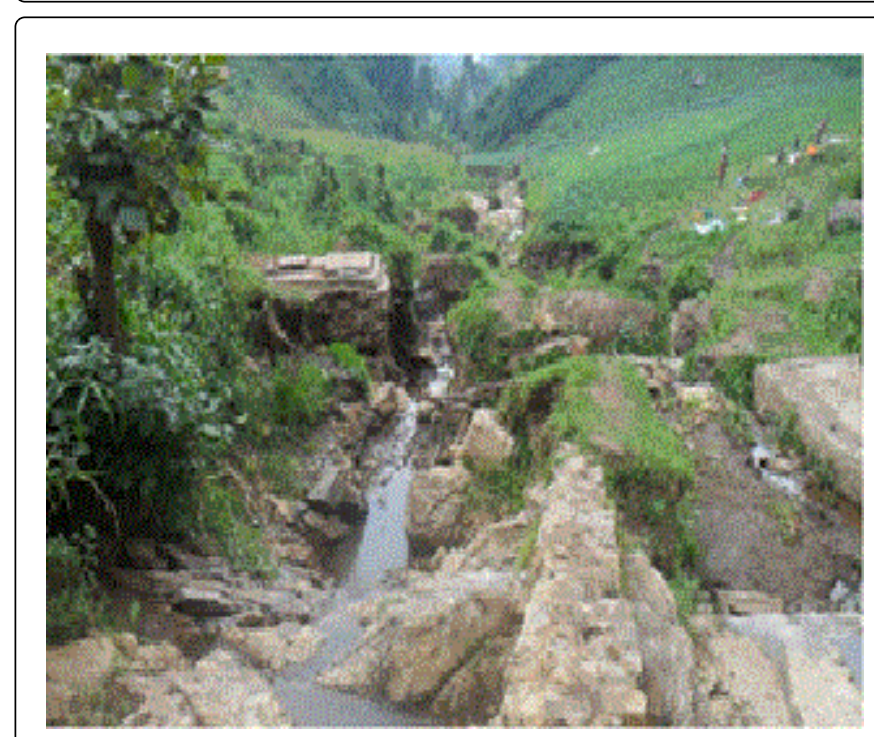

Figure 3: Destroyed gravity water source in Rutegyengyere.

According to Kabale District Planning Unit [24], during dry spells, some spring water sources dry up and cause water shortage in the area. Human settlement is on the lower areas of the hillsides near rivers and spring water areas. Water runoffs and discharges from kitchens, pit latrines and agricultural farmland flow directly into river and spring water (most especially during the rainy seasons). According to Environmental Protection Agency [25], people of the area depend on subsistence agriculture, majority live in temporary houses and the area experiences acute environmental degradation with no information on sustainable use of natural resources. In general, the area is characterized by poor settlement planning, lack of modern methods of farming, lack of defined water disinfection methods, low income generating activities, high illiteracy levels and low levels of public health concerns most especially water borne diseases. Therefore, there was a need to investigate the influence of various socio-economic factors on human health in Bufundi sub-county, and the generated information serves as baseline data for planning and environmental policy implementation.

\section{Methods and Materials}

\section{Study area}

The study was conducted from five villages in Bufundi Sub County, namely; Kacerere (KA), Rwakaroro (RW), Kashambya (KS), Kirwa (KI) and Quoters (QU). The socio-economic variables of interest include: years of education of the parent, water treatment methods, main source of water used in a household, and water storage methods. The physio-chemical and biological parameters of water for examination included: water colour and existence of organic materials (plant remains and animal materials), nitrate-nitrogen, nitritenitrogen, ammonium-nitrogen, fecal coli forms and total coli forms as colon forming units (CFU) per $100 \mathrm{ml}$ of water samples. The research design was particularly quantitative for all the parameters of interest in this study.

\section{Sampling design}

The sample size of 100 households was chosen in the five villages and 20 households were systematically selected from houses adjacent to each other in each village. The gender for the interviewees was chosen by alternating mother and father, from one household to another in each village. A comprehensive questionnaire was administered to each selected household that included the socioeconomic factors of interest. For water collection points in the communities, a total of eight sampling sites were chosen by simple random sampling as follows: 4 from the river and labelled R1, R2, R3 and R4; 3 from spring water and labelled S1, S2, and S3 and; 1 from gravity water sources labelled G1. All the sampling sites were (on average) 400 meters from each other.

\section{Sample handling}

From each sampling site, $250 \mathrm{ml}$ of water samples were collected in dried bottles cleaned with boiled water. Each sample was collected at 8.00 AM in the morning, transported to the laboratory in an icecooled container, and was processed for analysis in triplicates within 24 hours of collection.

\section{Reagents and instruments}

All reagents used were analytical grade. All the water used for both physio-chemical and biological analysis was de-ionized water to avoid any contamination. Nitra Ver 5 nitrate and Nitri Ver 3 Nitrite reagent powder pillows were supplied by HACH Company of USA. Nessler's reagent was supplied by $\mathrm{HACH}$ Company Inc. A HACH DR 5000 series spectrophotometer (made by HACH Company USA) was used in the determination of concentration of nitrate-nitrogen (detection limit: 0-30.00 $\mathrm{mgl}^{-1}$ ) and nitrite-nitrogen (detection limit LR: 0.002-0.3 $\mathrm{mgl}^{-1}$ ). A Spectronic Helios UV-Vis Spectrophotometer series (Made in England) was used in Nesslerization.

\section{Determination of nitrate-nitrogen}

A water sample $(10 \mathrm{ml})$ was added to an adapter inserted in a HACH DR 5000 series spectrophotometer programmed at wavelengths 
Citation: Safari D, Downs T, George M (2016) Impact of Socio-Economic Factors and Water Quality on Human Health in Rural Areas of Bufundi Sub County in Uganda: Implications for Policy and Practice. Adv Recycling Waste Manag 2: 118. doi:10.4172/2475-7675.1000118

Page 3 of 6

of $500 \mathrm{~nm}$. Then one Nitraver 5 nitrate reagent powder pillow was added and the instrument timer started. The reaction was left to run and shake the cell at breaks of 5 minutes until an amber colour appeared that confirmed the presence of nitrates. A blank was prepared and analyzed alternately with a water sample and results read and recorded directly in $\mathrm{mg} \mathrm{l}^{-1}$ of $\mathrm{NO}_{3}-\mathrm{N}$ from the instrument into the results table.

\section{Determination of ammonium-nitrogen}

To $5 \mathrm{ml}$ of the diluted and filtered sample in a clean test tube, $0.2 \mathrm{ml}$ of Nessler reagent were added and the mixture was shaken. The absorbance of the samples was measured using a Helios UV-Vis Scanning Spectrophotometer (detection limit $20 \mu \mathrm{g} \mathrm{l}^{-1}$ ) at $425 \mathrm{~nm}$ after 15 minutes against the blank sample. Ammonium-nitrogen concentrations were obtained directly from the calibration curve and recorded.

\section{Enumeration of coliforms}

To each sample, $50 \mathrm{ml}$ of water was filtered and the number of coli forms counted. At first, the samples were incubated at $35^{\circ} \mathrm{C}$ for 24 hours on endo type medium containing lactose and the red colonies with a metallic sheen that appeared were counted and recorded as total coliforms. To enumerate fecal coliforms, the filters were incubated on an enriched lactose medium (mFC) at a temperature of $44.5^{\circ} \mathrm{C}$ for 24 hours, and the blue colonies that appeared were counted as fecal coliforms. All counts were expressed as either total or fecal coliforms per $100 \mathrm{ml}$ of water. All water samples having one or more coliforms per $100 \mathrm{ml}$ were judged to be poor quality, based on zero tolerance level for coliforms in drinking water [26].

\section{Data analysis}

The coded data was analyzed using Microsoft Access and discriminant analysis (DA) in SPSS [27] for easy determination of which variables discriminate between the diseased and non-diseased groups of both diarrhea and skin infection. Variables considered under this analysis were: years of education, age of the parent, number of children less than five years per household and total number of people in each household. Descriptive statistics analysis was also used to determine how responses are distributed over the range of possible options for water sources, water storage, water appearance and water treatment. These variables were analyzed using SPSS and the results are reported with numbers and percentages for each response category. To determine the safe levels for drinking water, the chemical water quality indicators $\left(\mathrm{NO}_{3}-\mathrm{N}, \mathrm{NO}_{2}-\mathrm{N}\right.$ and $\mathrm{NH}_{4}-\mathrm{N}$ ) and biological (fecal and total coliforms) water quality indicators were compared with national and international guidelines.

\section{Results and Discussion}

\section{Socio-economic factors}

The results of the analysis model indicate that years of education of the parent and the total number of people per household are the best predictors of whether the household is likely to have a child below 5 years with diarrhea or not and skin infection or not due to their high classification coefficients indicated in (Equations 1 and 2).

Equation 1: Shows Fisher's coefficients to predict disease cases of diarrhea.
Diarrhea $=-78.449+2.156^{*}$ Age_parent $+4.541^{*}$ No_pple $+4.941^{*}$ Years_edu+0.692 ${ }^{*}$ No chdn_5

No disease $=-72.086+2.062^{*}$ Age_parent $+3.968^{*}$ No_pple
$+4.910^{*}$ Years_educ $+0.880^{*}$ Nochdn_5

Equation 2: Shows Fisher's coefficients to predict disease cases of skin infections

Skin infection $=-76.609+2.051^{*}$ Age_parent $+4.825^{*}$ No_pple $+4.902^{*}$ Years_edu $+.484^{*}$ No chdn_5

No infections $=-70.708+1.994^{*}$ Age_parent $+4.144^{*}$ No_pple $+4.826^{*}$ Years_educ $+0.696^{*}$ No chdn_5

The calculated Wilky's Lambda statistical value $(\mathrm{p}=0.001<0.05)$ suggests a rejection of the null hypothesis and shows that the model differentiates scores among groups (diseased and non-diseased) significantly (Table 1 ).

HO: The two groups have the same mean discriminant function scores; $\mu 1=\mu 2$

HA: The two groups have unequal mean discriminant function scores; $\mu 1 \neq \mu 2$

From the Table 1 below, (0.615)2 gives 0.378 , which means that the model explains $37.8 \%$ of variance in the grouping variable (diarrhea disease or no disease) for diarrhea cases. Thus, 615 indicates a moderate correlation between the discriminant scores of diarrheas diseased and non-diseased (Table 2).

\begin{tabular}{|l|l|l|l|l|}
\hline Functions & $\begin{array}{l}\text { Wilks' } \\
\text { Lambda }\end{array}$ & Chi-square & $\begin{array}{l}\text { Canonical } \\
\text { Correlation }\end{array}$ & Sig. \\
\hline $\begin{array}{l}\text { Diarrhea } \\
\text { disease }\end{array}$ & 0.621 & 30.946 & 0.615 & 0.001 \\
\hline Skin infection & 0.667 & 25.484 & 0.577 & 0.001 \\
\hline
\end{tabular}

Table 1: Wilk's Lambda for disease groups.

\begin{tabular}{|c|c|c|c|c|}
\hline \multirow[t]{2}{*}{ Variable } & \multicolumn{2}{|c|}{$\begin{array}{l}\text { Diarrhea in under } \\
\text { fives }\end{array}$} & \multicolumn{2}{|c|}{$\begin{array}{l}\text { Skin infection in under } \\
\text { fives }\end{array}$} \\
\hline & $\begin{array}{l}\text { 1- } \\
\text { Diarrhea }\end{array}$ & $\begin{array}{l}\text { 2-No } \\
\text { disease }\end{array}$ & $\begin{array}{l}\text { 1- } \\
\text { Infection }\end{array}$ & $\begin{array}{l}\text { 2-No } \\
\text { infection }\end{array}$ \\
\hline Age of the parent & 2.156 & 2.062 & 2.051 & 1.994 \\
\hline No. of people/household & 4.541 & 3.968 & 4.825 & 4.144 \\
\hline $\begin{array}{l}\text { Years of education of the } \\
\text { pa }\end{array}$ & 4.941 & 4.910 & 4.902 & 4.826 \\
\hline No. of children under five & 0.692 & 0.880 & 0.484 & 0.696 \\
\hline (Constant) & -78.449 & -72.086 & -76.609 & -70.708 \\
\hline
\end{tabular}

Table 2: Classification function coefficients for diarrhea and skin infection cases.

The Wilk's lambda value in the table provides proportion of the total variability not explained by the model. Results from this analysis (Table 3) show that $62.1 \%$ of the total variance in the discriminant scores is not explained by the differences among the groups. The Chisquare, 30.946 is significant $(p=0.001<0.05)$ at $95 \%$ level of confidence indicating that the group means differ for diarrhea case. 
Citation: Safari D, Downs T, George M (2016) Impact of Socio-Economic Factors and Water Quality on Human Health in Rural Areas of Bufundi Sub County in Uganda: Implications for Policy and Practice. Adv Recycling Waste Manag 2: 118. doi:10.4172/2475-7675.1000118

Page 4 of 6

\begin{tabular}{|l|l|l|l|l|}
\hline \multirow{2}{*}{ Variable } & \multicolumn{2}{|l|}{ Diarrhea } & \multicolumn{2}{l|}{ Skin Infection } \\
\cline { 2 - 5 } & $\begin{array}{l}\text { Wilks' } \\
\text { Lambda }\end{array}$ & Sig. & $\begin{array}{l}\text { Wilks' } \\
\text { Lambda }\end{array}$ & Sig. \\
\hline Age of the parent & 0.667 & 0.001 & 0.732 & 0.001 \\
\hline No. of people/household & 0.645 & 0.001 & 0.679 & 0.001 \\
\hline Years of education & 0.702 & 0.001 & 0.756 & 0.001 \\
\hline No. of children under five & 0.937 & 0.037 & 0.940 & 0.046 \\
\hline
\end{tabular}

of children under the age of five in a household is less significant in exposing young children to risks of diarrhea and skin infection $(\mathrm{p}=0.037$ and $\mathrm{p}=0.46$ respectively), compared to the age of the parent, number of people per household and level of education of the parent $(\mathrm{p}=0.001)$ (Table 3).

Table 4 below shows that most of the population (62.5\%) use water from rivers or springs while others harvest and store rain water $(7.5 \%)$, have installed ordinary containers (5\%) and those that don't have any category of water storage were $3.8 \%$. Most of the respondents $(68.9 \%)$ believe that water used is of low quality due its appearance, presence of suspended particles and small organisms like worms. The most common method of water treatment known in the areas is water boiling (100\%) and the majority of the population (77.4\%) store boiled drinking water in closed containers like small neck bottles and jugs. Only a small number (20.8\%) use open water containers like buckets and pans to keep their boiled water for drinking.

The study also found out that children with aged parents /guardians were at a high risk of suffering from the diseases compared to those with young parents/guardian. The study also revealed that the number

\begin{tabular}{|l|l|l|l|l|l|l|l|l|l|}
\hline Water Sources & Freq & \% age & Quality awareness & Freq & \% age & $\begin{array}{l}\text { Treatment } \\
\text { storage }\end{array}$ & $\begin{array}{l}\text { and } \\
\text { Age }\end{array}$ & Freq & Bo \\
\hline Water tank & 6 & 7.5 & Dirty/cloudy & 51 & 68.9 & Boiling & 64 & 100 \\
\hline Drum/bucket & 4 & 5.0 & Small organisms/worms & 17 & 23.0 & Missing & 37 & \\
\hline Rain & 3 & 3.8 & Chemical contamination & 3 & 4.1 & Open container & 72 & 77.4 \\
\hline River/spring & 50 & 62.5 & Bad smell/taste & 2 & 2.7 & Closed container & 21 & 22.6 \\
\hline Well & 13 & 16.3 & Not sure & - & 1 & 1.4 & Missing & 8 & - \\
\hline Not sure & 4 & 5.0 & - & - & - & - & & - & - \\
\hline
\end{tabular}

Table 4: Frequency distribution of water source, storage and treatment.

\section{Chemical factors}

Findings from this study show that there was high ammoniumnitrogen in river water compared to spring and gravity water sources (Table 5 and Figure 5). These high concentrations of ammoniumnitrogen in water samples are attributed to discharges from kitchen, local brewing areas, rotting surface vegetation and animal wastes from grazing areas. A very low concentration of nitrite-nitrogen is recorded at only one spot of spring water relative to the rest of the water sources (Table 5 and Figure 4). Results also indicate spring and gravity water to have relatively high concentrations of nitrate-nitrogen. However, the nitrogenous compound values observed at all sites are below both national and international guidelines of $10 \mathrm{mg} / \mathrm{ml}$ for each parameter considered hence there was low level of water pollution by nitrogen nutrients.

\begin{tabular}{|c|c|c|c|c|c|}
\hline Sample ID & $\mathrm{NH}_{4}-\mathrm{N}\left(\mathrm{mgl}^{-1}\right)$ & $\mathrm{NO}_{2}-\mathrm{N}\left(\mathrm{mgl}^{-1}\right)$ & $\mathrm{NO}_{3}-\mathrm{N}\left(\mathrm{mgl}^{-1}\right)$ & Coliforms (CFU/100 ml) & \\
\hline & & & & Fecal coliforms & Total coliforms \\
\hline R1 & 0.423 & 0.004 & 0.309 & 0.000 & 13.000 \\
\hline R2 & 0.294 & 0.017 & 0.112 & 0.000 & 170.000 \\
\hline R3 & 0.248 & 0.021 & 0.209 & 0.000 & 430.000 \\
\hline R4 & 0.271 & 0.021 & 0.078 & 0.000 & 650.000 \\
\hline S1 & 0.241 & 0.000 & 0.223 & 0.000 & 9.000 \\
\hline S2 & 0.166 & 0.004 & 1.367 & 0.000 & 0.000 \\
\hline S3 & 0.218 & 0.000 & 1.735 & 0.000 & 0.000 \\
\hline G1 & 0.121 & 0.000 & 0.394 & 0.000 & 0.000 \\
\hline National guidelines & N/A & 3.000 & 50.000 & 50.000 & 100.000 \\
\hline
\end{tabular}


Citation: Safari D, Downs T, George M (2016) Impact of Socio-Economic Factors and Water Quality on Human Health in Rural Areas of Bufundi Sub County in Uganda: Implications for Policy and Practice. Adv Recycling Waste Manag 2: 118. doi:10.4172/2475-7675.1000118

Page 5 of 6

\begin{tabular}{|l|l|l|l|l|l|}
\hline International guidelines & N/A & 1.000 & 10.000 & 0.000 & 0.000 \\
\hline
\end{tabular}

Table 5: Average chemical and microbiological water composition.

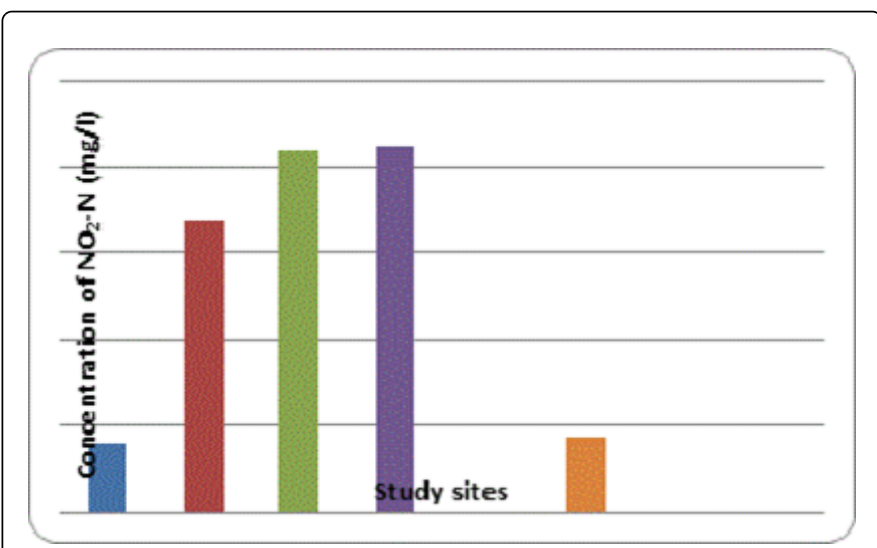

Figure 4: Variation of nitrite-nitrogen at various study sites.

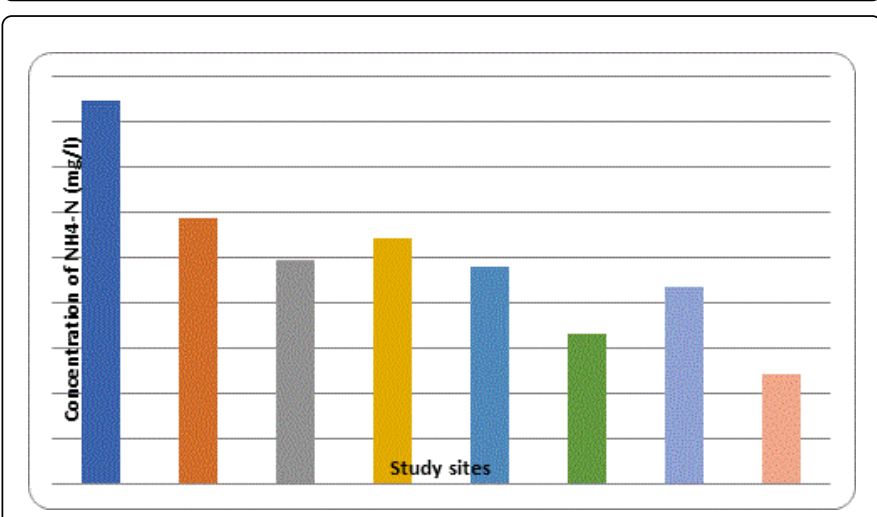

Figure 5: Variation of ammonium-nitrogen at various study sites.

\section{Biological factors}

The concentration of fecal coliforms was $0 \mathrm{CFU} / 100 \mathrm{ml}$ of water sample in all the water samples from the river, spring and gravity water (Table 5 and Figure 6). However, there were high counts of total coliforms detected in river samples compared to spring and gravity water samples. The absence of fecal coliforms in water samples indicated that water was free from fecal material at the time of sampling. Sampling stations $\mathrm{R}_{4}, \mathrm{R}_{3}$ and $\mathrm{R}_{2}$ have high total coliforms of 650 (which is more than 6 times the recommended level in the national guidelines), 430 and $170 \mathrm{CFU} / 100 \mathrm{ml}$ respectively. Results show that sampling station S1 was the only spring water study site that registered total coliforms $(9 \mathrm{CFU} / 100 \mathrm{ml}$ ) probably due to its location in a valley surrounded by homesteads on gentle slopes of hills. Gravity water sample indicated no contamination with total coliforms per 100 $\mathrm{ml}$ of water sample. The presence of total coliforms other than fecal coliforms to some sources of water is associated with environmental sources rather than fecal materials from human beings. This agrees with findings by Ref. [28] who demonstrates that total coliform bacteria are common in the environment like soil or vegetation, and are generally harmless.

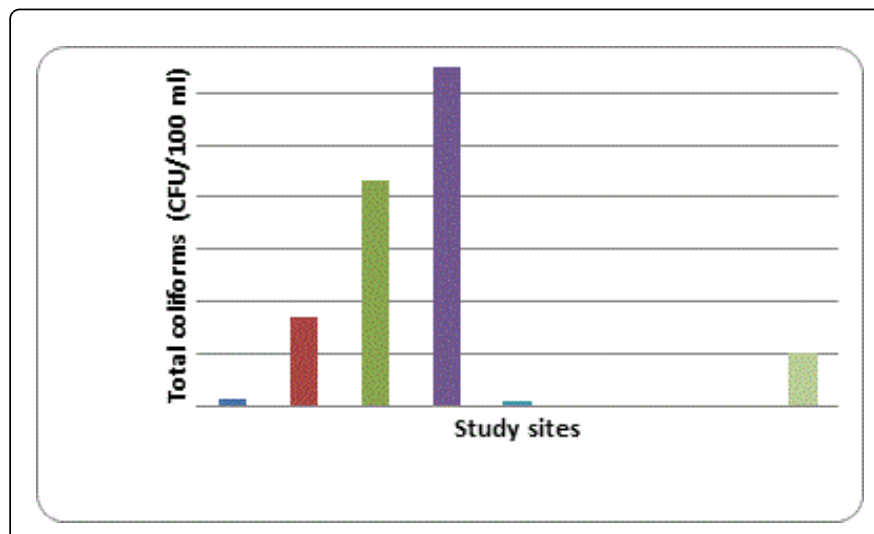

Figure 6: Variation of total coliforms at different study sites.

\section{Conclusion}

From the results, the level of education and number of children under the age of five in a household are better predictors of diarrhea and skin infection in Bufundi Sub county (Tables 2 and 3). This is also supported by the calculated Fischer's coefficients as shown in equations 1 and 2, and Table 2. In addition, the study found out that children with aged parents/guardians were at more risk of suffering from the diseases compared to those with young parents/guardians. All the water sources show low pollution levels as observed from results (Table 5) by comparing with international guidelines-10 mg.l-1 [29] of nitrate-nitrogen. However, the study shows that consumption of untreated river water is riskier than consumption of spring and gravity water (Table 5 and Figure 6). There are high levels of total coliforms in water sources especially river waters but no fecal coliforms observed at any source. The high levels of total coliforms are attributed to environmental sources rather than human fecal materials. The most common method of water treatment in rural areas in Uganda is boiling water for drinking. However, this method is inefficient in removing toxic substances or chemicals. Boiling water only kills some microorganisms but has no impact on other toxic substances. Studies by Ref. [30,31] have associated use of water of poor quality to the transmission of infectious diseases such as diarrhea, cholera and skin diseases in the tropics. There is need to conduct environmental health education and promote appropriate family planning methods in Bufundi sub county to reduce the risk of exposure to environmental related diseases.

\section{Acknowledgements}

Special thanks go to Ford Foundation-International Fellowships Program, who generously funded this research. We also extend appreciation to the Department of Biochemistry, Maker ere University Kampala, Uganda, for the assistance rendered in water sample analysis. 
Citation: Safari D, Downs T, George M (2016) Impact of Socio-Economic Factors and Water Quality on Human Health in Rural Areas of Bufundi Sub County in Uganda: Implications for Policy and Practice. Adv Recycling Waste Manag 2: 118. doi:10.4172/2475-7675.1000118

Page 6 of 6

\section{References}

1. World Health Organizations (1993) Guidelines for Drinking - Water Quality. 2nd edn.

2. Wright J, Gundry S, Conroy R (2004) Household drinking water in developing countries: a systematic review of microbiological contamination between source and point-of-use. Trop Med Int Health 9: 106-117.

3. Boisson S, Kiyombo M, Sthreshley L, Tumba S, Makambo J (2010) Field Assessment of a Novel Household-Based Water Filtration Device: A Randomized, Placebo-Controlled Trial in the Democratic Republic of Congo. PLoS ONE 5: e12613.

4. PACN (2010) Africa's Water Quality: A Chemical Science Perspective. Joint Royal Society of Chemistry and Syngenta UK Report.

5. World Resources Institute (WRI) (2009) Earth Trends: The Environmental Information Portal. WRI.

6. Kelly C, Taplin D, Allen AM (1971) Streptococcal ecthyma, Treatment with benzathine penicillin G. Arch Dermatol 103: 306-310.

7. Cairncross S, Blumenthal U, Kolsky P, Moraes L, Tayeh A (1996) The public and domestic domains in the transmission of disease. Tropical Medicine and International Health 1: 27-34.

8. Bailey R, Downes B, Downes R, Mabey D (1991) Trachoma and water use: a case control study in a Gambian village. Trans R Soc Trop Med Hyg 85: 824-828.

9. Van Buynder PG, Gaggin JA, Martin D, Pugsley D, Mathews JD (1992) Streptococcal infection and renal disease markers in Australian aboriginal children. Med J Aust 156: 537-540.

10. Swerdlow DL, Mintz ED, Rodriguez M (1992) Waterborne transmission of epidemic cholera in Trujillo, Peru: lessons for a continent at risk. Lancet 340: 28-33.

11. Streeton CL, Hanna JN, Messer RD, Merianos A (1995) An epidemic of acute post-streptococcal glomerulonephritis among aboriginal children. J Paediatr Child Health 31: 245-248.

12. Rotter ML (1999) Handwashing and hand disinfection. In: Mayhall CG (edn). Hospital epidemiology and infection control. 2nd edn. Philadelphia: Lippincott, Williams and Wilkins, pp: 1339-1355.

13. Jensen PK, Ensink, JHJ, Jayasinghe G, Van Der Hoek W, Cairncross S, et al. (2002) Domestic transmission routes of pathogens: the problem of inhouse contamination of drinking water during storage in developing countries. Tropical Medicine \& International Health 7: 604-609.

14. Clasen T, Roberts I, Rabie T, Schmidt W, Cairncross S (2006) Interventions to improve water quality for preventing diarrhoea. Cochrane Database of Systematic Reviews 3.

15. Curtis V, Cairncross S, Yonli R (2000) Domestic hygiene and diarrhea pinpointing the problem. Tropical Medicine and International Health 5: 22-32.
16. Rose JB, Epstein PR, Lipp EK (2001) Climate variability and change in the United States: Potential impacts of water- and food borne diseases caused by microbiologic agents. Environ Health Perspect 109: 211-219.

17. WHO (2012) Global Health Observatory: Mortality and Burden of Disease from Water and Sanitation.

18. Kaltenthaler E, Waterman R, Cross P (1991) Faecal indicator bacteria on the hands and the effectiveness of hand-washing in Zimbabwe. Journal of Tropical Medicine and Hygiene 94: 358-363.

19. Luby SP, Agboatwalla M, Raza A, Sobel J, Mintz ED, et al. (2001) Microbiologic effectiveness of hand washing with soap in an urban squatter settlement, Karachi, Pakistan. Epidemiology of Infections 127: 237-244

20. Lanata CF, Huttly SR, Yeager BA (1998) Diarrhea: whose feces matter? Reflections from studies in a Peruvian shanty town. Pediatric Infectious Disease Journal 17: 7-9.

21. Curtis V, Cairncross S (2003) Effect of washing hands with soap on diarrhea risk in the community: a systematic review. Lancet Infectious Diseases 3: 275-281.

22. Sobsey M (2002) Managing water in the home: accelerating health gains from improved water supply. World Health Organization, Geneva.

23. Sobsey MD, Stauber CE, Casanova LM, Brown JM, Elliott MA (2008) Point of use household drinking water filtration: A practical, effective solution for providing sustained access to safe drinking water in the developing world. Environ Sci Technol 42: 4261-4267.

24. Kabale District Planning Unit, Population and Housing Census (2002).

25. Environmental Protection Agency (2002) National Primary Drinking Water Regulations.

26. Leclerc HDAA (2001) Advances in the bacteriology of the coliform group: their suitability as markers of microbial water safety. Annual Reviews in Microbiology 55: 201-234

27. Poulsen J, French A (2011) Discriminant Function Analysis, pp: 1-7.

28. Directorate of Water Development (DWD), Ministry of Water and Environment (2010)

29. Porter MJ (1977) An epidemiological approach to skin disease in the tropics. Trop Doct 7: 59-66.

30. Lye DJ (2002) Health Risks Associated With Consumption of Untreated Water from Household Roof Catchment Systems. Journal of American Water Resources Association 38: 1301-1306.

31. Food and Drug Administration (2008) Coliform bacteria and drinking water. 